Wind Energ. Sci. Discuss., doi:10.5194/wes-2016-34, 2016

Manuscript under review for journal Wind Energ. Sci.

Published: 28 September 2016

(c) Author(s) 2016. CC-BY 3.0 License.

(c) (i)

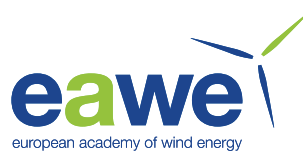

\title{
FLOWSTAR-Energy: a high resolution wind farm wake model
}

\author{
Amy Stidworthy ${ }^{1}$, David Carruthers ${ }^{1}$ \\ ${ }^{1}$ CERC Ltd, 3 Kings Parade, Cambridge, CB2 1SJ, UK \\ Correspondence to: Amy Stidworthy (amy.stidworthy@cerc.co.uk)
}

5 Abstract. A new model, FLOWSTAR-Energy, has been developed for the practical calculation of wind farm energy production. It includes a semi-analytic model for airflow over complex surfaces (FLOWSTAR) and a wind turbine wake model that simulates wake-wake interaction by exploiting some similarities between the decay of a wind turbine wake and the dispersion of plume of passive gas emitted from an elevated source. Additional turbulence due to the wind shear at the wake edge is included and the assumption is made that wind turbines are only affected by wakes from upstream wind turbines. The model takes account of the structure of the atmospheric boundary layer, which means that the effect of atmospheric stability is included. A marine boundary layer scheme is also included to enable offshore as well as onshore sites to be modelled.

FLOWSTAR-Energy has been used to model three different wind farms and the predicted energy output compared with measured data. Maps of wind speed and turbulence have also been calculated for two of the wind farms. The Tjaæreborg

15 wind farm is an onshore site consisting of a single $2 \mathrm{MW}$ wind turbine, the NoordZee offshore wind farm consists of 36 V90 VESTAS 3 MW turbines and the Nysted offshore wind farm consists of 72 Bonus $2.3 \mathrm{MW}$ turbines. The NoordZee and Nysted measurement datasets include stability distribution data, which was included in the modelling. Of the two offshore wind farm datasets, the Noordzee dataset focuses on a single 5-degree wind direction sector and therefore only represents a limited number of measurements $(1,284)$; whereas the Nysted dataset captures data for seven 5-degree wind direction sectors and represents a larger number of measurements $(84,363)$. The best agreement between modelled and measured data was obtained with the Nysted dataset, with high correlation ( 0.98 or above) and low normalised mean square error ( 0.007 or below) for all three flow cases. The results from Tjæreborg show that the model replicates the Gaussian shape of the wake deficit two turbine diameters downstream of the turbine, but the lack of stability information in this dataset makes it difficult to draw conclusions about model performance.

25 One of the key strengths of FLOWSTAR-Energy is its ability to model the effects of complex terrain on the airflow. However, although the airflow model has been previously compared extensively with flow data, it has so far not been used in detail to predict energy yields from wind farms in complex terrain. This will be the subject of a further validation study for FLOWSTAR-Energy. 
Wind Energ. Sci. Discuss., doi:10.5194/wes-2016-34, 2016

Manuscript under review for journal Wind Energ. Sci.

Published: 28 September 2016

(c) Author(s) 2016. CC-BY 3.0 License.

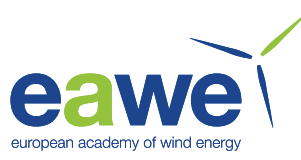

\section{Introduction}

Wind turbines generate electricity by extracting energy from the wind; this process creates a 'wake' downwind of the turbine. When wind turbines are sited individually or far apart, the effects of wind turbine wakes on the energy generation of other turbines is insignificant. However, wind turbines are often grouped together into wind 'farms' for greater efficiencies

5 in terms of land use, operation and maintenance. Wake effects within a wind farm can cause significant power losses; up to $40 \%$ in some cases (e.g. Barthelmie et al., 2009). The greatest wake losses occur where the wind speed is below the 'rated wind speed' of a turbine, typically 13 or $14 \mathrm{~ms}^{-1}$ at hub height, as is often the case. Below the rated wind speed, the energy a turbine extracts from the wind increases sharply with increasing wind speed; above the rated wind speed, blade pitch control mechanisms keep the turbine power output constant at the turbine's rated power level. Therefore, below the rated wind

10 speed, any reduction in wind speed, for example due to the wake from an upstream turbine, has a significant impact on power output. This loss of efficiency and potential for variability in wind farm energy production can be a serious problem for energy distribution authorities who operate complex energy networks. Therefore, it is important to account for wake effects both at the design stage of a wind farm and when predicting power output during operation.

In the study of wind turbine wakes, the 'near wake' is the term given to the part of the wake that is up to approximately two

15 turbine diameters downstream from the turbine; here, root and tip vortices generated by the turbine blades create a tubular shear layer. Beyond the complex near wake region is the part of the wake known as the 'far wake', where the wake can be characterised more simply as a region of reduced axial wind speed and increased turbulence levels (e.g. Sanderse et al., 2011). Over the past twenty years, models have been developed to study the aerodynamics of wind turbines and the behaviour of wind turbine wakes with varying levels of complexity, as reviewed in Sanderse et al., 2011. Simple kinematic

20 models only simulate the far wake; increasingly the trend is towards more complex computational fluid dynamics (CFD) methods that simulate the whole wake, including the complex near wake region. These models offer great insights into the behaviour of wind turbine wakes and are important for turbine design calculations, but require extensive computational resources and are not yet a practical tool for predicting wind farm energy production.

In this paper we describe a new model, FLOWSTAR-Energy, which has been developed for the practical calculation of wind

25 farm energy production. This includes a model for airflow and turbulence over complex terrain and a novel plume-based method for the downstream development of turbine wakes. FLOWSTAR-Energy is described in Section Error! Reference source not found. and we present validation of the wake model for three sites in Section Error! Reference source not found..

\section{Model description}

30 FLOWSTAR-Energy comprises a semi-analytic model for airflow over complex surfaces (FLOWSTAR) together with a wind turbine wake model including wake-wake interaction and impacts on the mean flow. FLOWSTAR has previously been described (Carruthers et al, 1988) and validated (Carruthers et al., 2014, Stocker et al., 2016, CERC, 2016 - Askervein Hill 
Wind Energ. Sci. Discuss., doi:10.5194/wes-2016-34, 2016

Manuscript under review for journal Wind Energ. Sci.

Published: 28 September 2016

(c) Author(s) 2016. CC-BY 3.0 License.

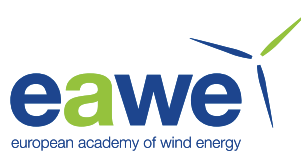

and Blashaval) and has been subject to extensive use as a component part of the Atmospheric Dispersion Modelling System (ADMS) (CERC, 2015). In essence it represents the lower atmosphere with three layers: a boundary layer; a capping inversion; and the free troposphere. It uses linearised flow equations together with a non-linear surface boundary condition. Near the surface the impact of shear stress perturbations on the mean flow is represented using a mixing length closure. The model takes account of spatial variations in both terrain elevation and surface roughness. The solution is continuous in the vertical and has a resolution in the horizontal direction as fine as the terrain data and/or computational resources allow.

The wind turbine wake model exploits some similarities between the decay of the wake behind a wind turbine and the dispersion of a plume of passive gas emitted from an elevated source: both are advected downstream and mix with ambient air, which in the case of the wake decreases its intensity and in the case of the plume decreases the concentration of gas in

10 the plume. The method is thus to represent the fully-expanded wind turbine wake immediately downwind of a wind turbine by a cuboid-shaped 'volume source' that passively 'emits' the wind speed deficit. The model uses 1-D momentum theory to determine the maximum wind speed deficit in the far wake from turbine thrust coefficient data, which is used to determine the volume source strength and dimensions. The wind speed deficit is the quantity which is then 'dispersed' downwind. This dispersion calculation is conducted using ADMS, modified to include the additional shear-induced turbulence in the wake.

15 The overall wake within and downstream of groups of turbines (i.e. a wind farm) is modelled by considering the wake effects from individual wind turbines in downstream order, so that wakes from upstream wind turbines affect the flow field used when characterising the downstream wind turbine volume sources and when dispersing their wakes.

\subsection{Representation of a wind turbine as an effective volume source}

Figure 1 shows a schematic diagram of the expanding stream-tube of flow through a turbine together with the effective 20 volume source used in the model.

According to classical 1-D momentum theory (e.g. Hansen, 2008), the maximum wind speed deficit in a fully expanded wind turbine wake is equal to $2 a U$ and the maximum wind speed deficit in the partially expanded wake at the turbine is equal to $a U$, where $U$ is the upstream wind speed at hub height in units of $\mathrm{ms}^{-1}$ and $a$ is known as the 'axial induction factor'. Following 0 , the axial induction factor $a$ is related to the thrust coefficient $C_{T}$ as follows:

$25 C_{T}=\left\{\begin{array}{cc}4 a(1-a), & a \leq a_{c} \\ 4\left(a_{c}^{2}+\left(1-2 a_{c}\right) a\right), & a>a_{c}\end{array}\right.$,

where $a_{c} \approx 0.2$. Thus, Eq.

(1) can be used to write an expression for $a$ as a function of $C_{T}$ :

$a=\left\{\begin{array}{cc}\frac{1}{2}\left(1-\sqrt{1-C_{T}}\right) & C_{T} \leq 0.64 \\ \frac{C_{T}-4 a_{c}{ }^{2}}{4\left(1-2 a_{c}\right)} & C_{T}>0.64\end{array}\right\}$. 
Wind Energ. Sci. Discuss., doi:10.5194/wes-2016-34, 2016

Manuscript under review for journal Wind Energ. Sci.

Published: 28 September 2016

(c) Author(s) 2016. CC-BY 3.0 License.

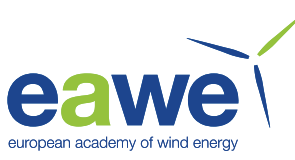

Conservation of mass in the expanding stream-tube leads to a relationship between the diameter of the fully expanded wake

$D_{W}$ and the diameter of the turbine rotor $D$ :

$D_{W}=D \sqrt{\frac{(1-a)}{(1-2 a)}}$.

For pragmatic reasons the initial cross-section of the volume source is taken as square rather than circular, but this has little

5 impact on the developing wake. The dimensions of the source are calculated so that the crosswind area is equal to that of the fully expanded wake, hence:

$d y=d z=\frac{D}{2} \sqrt{\frac{\pi(1-a)}{(1-2 a)}}$

where $d y$ is the horizontal crosswind extent of the volume source and $d z$ is the depth of the volume source. The along-wind extent of the volume source is set to ten percent of the crosswind extent $d y$. Since modern wind turbines have quick and

10 efficient mechanisms to bring the wind turbine rotor perpendicular to the inflow wind, the model assumes zero yaw, therefore the volume source is aligned perpendicular to the upstream wind.

The volume source strength is calculated using concentration as a surrogate for the wind speed deficit. The maximum wind speed deficit $\Delta U_{\max }$ can be expressed as

$\Delta U_{\max }=\frac{Q V_{s r c}}{\dot{V}}$,

15 where $Q$ is the source strength (in units of $\mathrm{ms}^{-2}$ ), $V_{s r c}$ is the source volume, and $\dot{V}$ is the volume flow rate through the source; therefore,

$Q=\frac{2 a U^{2}}{0.1 d y}$

Note that the volume source produces initial 'top-hat' vertical and horizontal profiles of wind speed deficit, which decay to Gaussian-shape profiles as they evolve downstream.

\section{2 'Dispersion' of the 'source'}

The effective volume source representing the initial wind speed deficit in the wake is decomposed into a maximum of ten thin crosswind source elements, where the width of each source element is a function of the proximity of the element to the receptor, while the difference in streamwise distance between source elements and the receptor is constrained not to vary too rapidly. The wake deficit at each receptor is then calculated by summing the contributions from each element.

25 The wake deficit contribution $\overline{\bar{C}}(x, y, z)$ calculated for each element from a crosswind vertical slice of length $L_{s}$ and height $L_{1}$ is given by Eq. (7). 
Wind Energ. Sci. Discuss., doi:10.5194/wes-2016-34, 2016

Manuscript under review for journal Wind Energ. Sci.

Published: 28 September 2016

(c) Author(s) 2016. CC-BY 3.0 License.

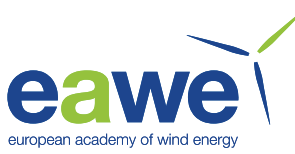

$\overline{\bar{C}}(x, y, z)=\frac{\bar{Q}_{s}}{4 U}\left[\operatorname{erf}\left(\frac{y+\frac{1}{2} L_{s}}{\sigma_{y} \sqrt{2}}\right)-\operatorname{erf}\left(\frac{y-\frac{1}{2} L_{s}}{\sigma_{y} \sqrt{2}}\right)\right] \times\left[\operatorname{erf}\left(\frac{z+\frac{1}{2} L_{1}-z_{s}}{\sigma_{z} \sqrt{2}}\right)-\operatorname{erf}\left(\frac{z-\frac{1}{2} L_{1}-z_{s}}{\sigma_{z} \sqrt{2}}\right)\right]+$ reflection terms

The source strength $\overline{\bar{Q}}_{s}$ is in units of $\mathrm{ms}^{-2}$.

Field experiments and research have shown that the dispersion parameters $\sigma_{y}$ and $\sigma_{z}$ vary with downwind distance $x$ from a source of airborne emitted material in a way that depends on: the atmospheric boundary layer height (h); the Monin

5 Obukhov length $\left(L_{M O}\right)$, which is a measure of atmospheric stability; height of the source $\left(z_{s}\right)$; and the height of the plume as it travels downwind. For reviews of this subject, see Hunt et al., 1988a, Hanna and Paine, 1989 and Weil, 1985. The approach adopted is to use formulae that have been developed and broadly accepted for specific ranges of the parameters $z_{s} / h$ (source height), $h / L_{M O}$ (stability) and $x / h$ (downwind distance). Interpolation formulae have then been constructed to cover the complete parameter range. The basis for these formulae is set out at length in Hunt et al., 1988a.

\section{$10 \quad$ 2.3 Shear-induced turbulence}

At the edge of a turbine wake there is a gradient in the speed of the air flow, which generates additional turbulence. Based on Bevilaqua and Lykoudis, 1978, an extra component of turbulence, $\sigma_{\text {shear }}$, has been included as follows:

$\sigma_{\text {shear }}[i+1]=\left\{\begin{array}{cc}0.4|\Delta U| \frac{x}{X_{\text {crit }}}, & x \leq X_{\text {crit }} \\ \sigma_{\text {shear }}[i] \times e^{-d t / t}, & x>X_{\text {crit }}\end{array}\right.$,

where $x$ is the downwind distance from the effective volume source and $|\Delta U|$ is the local wind speed deficit. Here, $i$ and

$15 i+1$ represent consecutive calculation points in a downstream direction along the wake centreline; $d t$ represents the time taken by the wake centreline to travel from the $i$ th to the $(i+1)$ th point. $t$ represents the time taken by the plume to spread the width (depth) of the wake:

$t=\frac{2 R}{\sigma_{t o t}}$.

$R$ is the wake radius, defined as the effective volume source half-width plus the local plume spread, calculated at a given point as a weighted average over all upstream wakes; $\sigma_{\text {tot }}$ is the combination of the upstream turbulent velocity and the local shear-induced turbulence:

$\sigma_{\text {tot }}[i+1]=\sqrt{\sigma_{\text {shear }}[i]^{2}+\sigma[i+1]^{2}}$.

$X_{\text {crit }}$ is a critical distance, which is the distance downstream from the effective source at which $\sigma_{\text {shear }}$ starts to decay and is dependent on the inflow turbulence. For inflows with low turbulence, the shear-induced turbulence increases from zero at the

25 turbine to a maximum at $X_{c r i t}$, in proportion with the local wind speed deficit, and then decays; for turbulent inflows, the initial value of $\sigma_{\text {shear }}$ is $0.4|\Delta U|$ at the wind turbine and it decays immediately. $X_{\text {crit }}$ is defined as 
Wind Energ. Sci. Discuss., doi:10.5194/wes-2016-34, 2016

Manuscript under review for journal Wind Energ. Sci.

Published: 28 September 2016

(c) Author(s) 2016. CC-BY 3.0 License.

(c) (i)

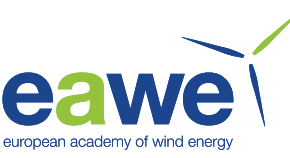

$X_{\text {crit }}=\left\{\begin{array}{cc}4 D & T I \leq T I_{\text {lower }} \\ 4 D\left[1-\frac{\left(T I-T I_{\text {lower }}\right)}{\left(T I_{\text {upper }}-T I_{\text {lower }}\right)}\right] & T I_{\text {lower }}<T I<T I_{\text {up per }} . \\ 0 & T I \geq T I_{\text {upper }}\end{array}\right.$

The inflow turbulence is characterised by the turbulence intensity $T I$, which is expressed as a percentage and represents the ratio of the horizontal turbulence to the horizontal mean flow. TI is defined as

$T I=100 \times \frac{\sqrt{\sigma_{u}^{2}+\sigma_{v}^{2}}}{\sqrt{u^{2}+v^{2}}}$.

$5 T I_{\text {lower }}$ and $T I_{\text {upper }}$ are threshold values determined during validation of the model; these are set to $12 \%$ and $18 \%$ respectively.

\subsection{Treatment of wind turbine interaction}

Before the wake calculations are carried out for each input meteorological condition all the input wind turbines are reordered according to their downwind position. The assumption is made that wind turbines are only affected by the wakes

10 from upstream wind turbines. The flow field is modified by each wind turbine wake and includes the effect of the wakes from all upstream wind turbines.

The perturbation of the flow field by each wind turbine is represented by adjusting the values of the velocity components from the input flow field to include the calculated wind speed deficit. This is done over a grid of points covering the modelling region and the wind turbine locations at a range of heights within the atmospheric boundary layer. This process is

15 repeated iteratively to apply the effect of each wind turbine in downstream order. The change in the flow field for each wind turbine in a wind farm affects the characterisation of the effective volume source and the dispersion of the wake.

\subsection{Marine boundary layer scheme}

For offshore sites, FLOWSTAR-Energy includes a marine boundary layer scheme for calculating surface roughness and heat fluxes.

20 For surface roughness $z_{0}$ the formula of Beljaars, 1994, has been adopted, as used by the European Centre for Medium-range Weather Forecasts (ECMWF):

$z_{0}=\alpha_{m} \frac{v}{u_{*}}+\alpha_{C h} \frac{u_{*}^{2}}{g}$

where $u_{*}\left(\mathrm{~ms}^{-1}\right)$ is the friction velocity, $v\left(\mathrm{~m}^{2} \mathrm{~s}^{-1}\right)$ is the kinematic viscosity of air, $g$ is the acceleration due to gravity $\left(\mathrm{ms}^{-2}\right)$, $\alpha_{m}=0.11$ and $\alpha_{C h}$ is the Charnock parameter. $\alpha_{C h}=0.08$ is typical for an offshore site not remote from the coast.

25 Over the sea the surface roughness values for sensible heat $\left(z_{0 H}\right)$ and moisture $\left(z_{0 q}\right)$ are given by Beljaars, 1994, as

$z_{0 H}=\alpha_{H} \frac{v}{u_{*}}$ and $z_{0 q}=\alpha_{q} \frac{v}{u_{*}}$ 
Wind Energ. Sci. Discuss., doi:10.5194/wes-2016-34, 2016

Manuscript under review for journal Wind Energ. Sci.

Published: 28 September 2016

(c) Author(s) 2016. CC-BY 3.0 License.

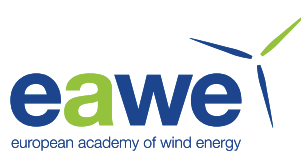

where $\alpha_{H}=0.4$ and $\alpha_{q}=0.62$.

The surface roughness for sensible heat is used to define velocity and concentration profiles, while the surface roughness for moisture is used to calculate the latent heat flux at the sea surface.

\section{Validation}

5 The three datasets used for model validation are the Tjæreborg $60 \mathrm{~m}$ single wind turbine dataset; the NoordZee wind farm dataset and the Nysted wind farm dataset. These datasets were a key component of the EU's TOPFARM project (Larsen et al., 2011); a summary of the datasets is provided in Table 1. The definitions of the statistical measures used to compare modelled and observed data are given in Table 2 .

\subsection{Tjæreborg $60 \mathrm{~m}$ Wind Turbine}

10 Wind speed measurements were recorded between 1988 and 1993 on two meteorological masts near to a wind turbine at Tjæreborg Enge wind farm in Esbjerg, Denmark, approximately $750 \mathrm{~m}$ downwind from the coast. The wind turbine hub height was $60 \mathrm{~m}$ and the rotor diameter $(D)$ was $61 \mathrm{~m}$. One of the masts, M1, was sited $122 \mathrm{~m}$ upstream of the turbine and the other mast, M2, was sited $122 \mathrm{~m}$ downstream of the turbine. The layout of the turbine and the measurement masts is shown in Figure 2. Wind speed measurements at mast M2 at heights 30, 45, 60 and $90 \mathrm{~m}$ have been categorised into four

15 flow cases based on the turbine hub height wind speed at mast M1: 6, 8, 10 and 12 $\pm 0.5 \mathrm{~ms}^{-1}$. The data have also been categorised according to the wind direction, in 1 degree intervals up to 40 degrees either side of the case where mast M2 is directly downstream of the turbine. The thrust coefficient $\left(C_{T}\right)$ and power curves for this turbine are shown in Figure 3 . The maximum theoretical value of $C_{T}$ is 1 , yet for wind speeds of 5,6 and $7 \mathrm{~ms}^{-1}$ the given value of $C_{T}$ is greater than 1 ; therefore in the modelling analysis $C_{T}=\min \left(C_{T}, 1\right)$.

20 The modelling for this case assumed a constant surface roughness of $0.005 \mathrm{~m}$; this is an appropriate value for the site, which is in flat, open grassland close to the sea. For each flow case, wind directions were modelled from 230 to 310 degrees inclusive, in 1 degree intervals with no wind direction sector averaging applied. In the absence of any additional meteorological data, or date and time information for the measurements, the modelling assumed neutral atmospheric stability.

25 The results presented in Figure 4 show the modelled and observed wind speed deficit at mast M2, normalised by the wind speed at mast M1, for all four flow cases as a function of wind direction offset, where 0 degrees represents the case where the mast M2 is directly downstream of the turbine. The results are averaged over the measurement heights 30, 45, 60 and 90 m.

There is generally good agreement between the modelled and observed wake deficit, and the model simulates the shape of

30 the wake deficit well. However, while the modelled and measured data show broadly the same behaviour, namely that as the wind speed increases the strength of the wake decreases, this behaviour is less marked in the observed data than in the 
Wind Energ. Sci. Discuss., doi:10.5194/wes-2016-34, 2016

Manuscript under review for journal Wind Energ. Sci.

Published: 28 September 2016

(c) Author(s) 2016. CC-BY 3.0 License.

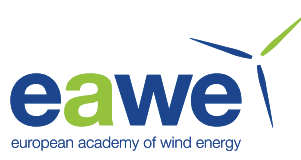

modelled data. The modelled wake has a tendency to be slightly wider than the observed wake in this case. This is likely to be related to the assumption of neutral stability and also to the assumption of uniform surface roughness in this complex location close to the sea.

\subsection{Noordzee Wind Farm}

5 The 'NoordZee' wind farm is an offshore wind farm in the North Sea approximately $10 \mathrm{~km}$ from the coast at Egmond aan Zee in the Netherlands (see Figure 5); it is operated jointly by NoordZee and OWEZ and consists of 36 V90 VESTAS 3 MW wind turbines.

Each wind turbine has a rotor diameter (D) of $90 \mathrm{~m}$ and a hub height of $70 \mathrm{~m}$. The turbine layout is an irregular grid, with 4 SE-NW rows containing unequal numbers of turbines. The wind farm layout is shown in Figure 6. 'Row 1' refers to turbines

10 wt01 to wt12; 'Row 2' refers to turbines wt13 to wt21; 'Row 3' refers to turbines wt22 to wt29; and 'Row 4' refers to turbines wt30 to wt36. 'Column 1' contains turbines wt01 and wt13; 'Column 2' contains turbines wt02, wt14 and wt22; 'Column 3' contains turbines wt03, wt15, wt23 and wt30; and so on. The spacing between turbines in each row is 7D, apart from between turbines 4 and 5 in rows 2, 3 and 4 where the spacing is 11D. The turbine power and thrust coefficient curves are given in Figure 7. The power output of each wind turbine was recorded at 10-minute intervals during the period 2006-

15 2007. These data have been filtered by the wind direction measured at the meteorological mast to leave only power measurements recorded when the wind direction was $139 \pm 2.5$ degrees; this was chosen as the wind direction leading to the greatest wake effects within the wind farm. The measurement data have been further categorised into three flow cases: 6,8 and $10 \mathrm{~ms}^{-1}$, each containing only measured data recorded when the hub height wind speed at the reference turbine wt 01 (derived from the measured power at wt01 and the power curve) is within $0.5 \mathrm{~ms}^{-1}$ of the flow case wind speed.

20 The NoordZee dataset used in this work provides the following information per wind turbine per flow case: the mean power output $(\mathrm{kW})$; the number of measurements used to calculate the mean power output; and the standard deviation of the measurements used to calculate the mean power output. The dataset also provides the distribution of measurements in terms of atmospheric stability classes, defined using the Monin-Obukhov length $\mathrm{L}_{\mathrm{MO}}$ as set out in Table 3 .

Modelling of the NoordZee wind farm was compared with the measurement dataset described above. The surface roughness

25 was calculated using the marine boundary layer scheme (described in section 0 ) and assuming neutral stability since no sea surface temperature data were available; the calculated values are given in Table 4. The wind farm modelling used the stability distribution and representative values of $\mathrm{L}_{\mathrm{MO}}$ given in Table 3. The modelled upstream wind speeds were the flow case wind speeds (the measured $\pm 0.5 \mathrm{~ms}^{-1}$ variation has not been accounted for in the modelling) and the modelled wind direction was a 5-degree sector centred on 139 degrees. Model output was predicted power output for each wind turbine.

30 Figure 8 shows graphs of the measured and modelled power output per turbine by row, column and flow case. The graphs also include the standard deviation of the measurements used to calculate the mean value and the number of 10-minute measurements from which the mean value was calculated for each turbine for each flow case. The statistical results in Table 
Wind Energ. Sci. Discuss., doi:10.5194/wes-2016-34, 2016

Manuscript under review for journal Wind Energ. Sci.

Published: 28 September 2016

(c) Author(s) 2016. CC-BY 3.0 License.

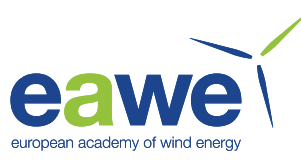

4 demonstrate that overall there is reasonable agreement between modelled and measured power output. Maps of modelled wind speed and turbulence intensity for the $8 \mathrm{~ms}^{-1}$ flow case are presented in Figure 9.

There are two issues with comparing the NoordZee dataset described above with modelled data: firstly, the categorisation of the data using the reference wind turbine wt01 means that any variation in wind speed between the upstream turbines is unaccounted for; secondly, the filtering of the measured data for a single 5 degree sector results in only a relatively small number of measurements with which to compare modelled results.

The model results capture most of the features that can be seen in the measured data, for example the sharp drop in power output between the first two turbines in each row and the increase in power from turbine 4 to turbine 5 in rows 2, 3 and 4 due to the increased turbine spacing. There are, however, features in the measured data not captured by the modelling, for

10 example in all three flow cases there is significant variation between the measured power values for the most upstream turbine in each row, which suggests that there is some spatial variation in the upstream flow, possibly due to the relatively close proximity of the coast, which has not been accounted for in the modelling. This is particularly marked in the $10 \mathrm{~ms}^{-1}$ flow case, where there is also some unexplained behaviour for rows 1 and 2 where the measured power appears to increase through the wind farm; however this is based on only a relatively small number of measurements. There is a small difference

15 between the modelled and measured power output for the reference turbine wt01 for each flow case; this is likely to be due to the $\pm 0.5 \mathrm{~ms}^{-1}$ variation in the upstream wind speed in the measurements, which is not included in the modelling.

\subsection{Nysted Wind Farm}

Nysted wind farm is a wind farm near the coast of Denmark (see Figure 10) consisting of 72 Bonus 2.3 MW turbines arranged in a parallelogram grid with 9 rows and 8 columns, with the rows at an angle of $8^{\circ}$ to the W-E direction. Each

20 turbine has diameter $82.4 \mathrm{~m}$ and height $69 \mathrm{~m}$. Nysted wind farm is operated by Dong Energy. The power output of each wind turbine was recorded at 10-minute intervals during the period 2004-2006. These data have been filtered by the wind direction measured on a meteorological mast to the west of the wind farm to leave only power measurements recorded when the wind direction was in the range 260.5 to 295.5 degrees. These data have been categorised into seven wind direction cases, each representing a 5 degree sector: 263, 268, 273, 278, 283, 288 and 293 degrees. The data have been further categorised into

25 three flow cases: 6,8 and $10 \mathrm{~ms}^{-1}$, each containing only measured data recorded when the hub height wind speed at the meteorological mast was within $0.5 \mathrm{~ms}^{-1}$ of the flow case wind speed. The layout of the turbines is shown in Figure 11, together with the 7 wind direction cases. In all wind direction cases, column A is the column furthest upstream and column $\mathrm{H}$ is the column furthest downstream. Wind turbines in column $\mathrm{A}$ are unaffected by wakes from other turbines for all the wind direction cases.

30 The Nysted wind farm dataset includes the following for each flow case and wind direction case: the mean power output $(\mathrm{kW})$; the number of measurements used to calculate the mean power output per turbine; and the standard deviation of the measurements used to calculate the mean power output. The dataset also provides the distribution of measurements in terms of a set of atmospheric stability classes that are defined using the Monin-Obukhov length $\mathrm{L}_{\mathrm{MO}}$ as set out in Table 5 . 
Wind Energ. Sci. Discuss., doi:10.5194/wes-2016-34, 2016

Manuscript under review for journal Wind Energ. Sci.

Published: 28 September 2016

(c) Author(s) 2016. CC-BY 3.0 License.

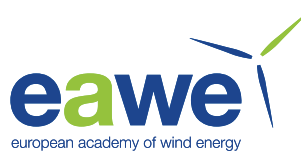

FLOWSTAR-Energy model calculations were compared with the measurement dataset described above. The surface roughness was calculated using the marine boundary layer scheme (described in section 0) and assuming neutral stability since no sea surface temperature data were available; the calculated values are given in Table 6. The wind farm modelling used the representative values of $1 / \mathrm{L}_{\mathrm{MO}}$ and the stability distribution given in Table 5 . The modelling used the power and thrust data for a Bonus 2.3 MW turbine shown in Figure 12. The modelled upstream wind speeds were the flow case wind speeds (the measured $\pm 0.5 \mathrm{~ms}^{-1}$ variation has not been accounted for in the modelling). The wind direction was modelled in sectors of 5 degrees, which means that 5 wind directions within each sector were modelled and the results are the average over the results from each sub-sector. Model output was predicted power output for each wind turbine.

The results of the analysis are presented in Figure 13 as a comparison between mean observed and modelled power (kW) for

10 each turbine for each of the three flow cases $\left(6,8\right.$ and $\left.10 \mathrm{~ms}^{-1}\right)$ averaged over all seven wind direction cases; Table 6 gives the total wind farm power from the measured and modelled datasets; and the correlation, fractional bias and normalised mean square error of the modelled dataset with respect to the measured dataset. Maps of modelled wind speed and turbulence intensity for the $10 \mathrm{~ms}^{-1}$ flow case are presented in Figure 14.

The model performance overall is very good and the agreement between modelled and measured results improves as the

15 mean inflow wind speed increases. The model captures the main features in the measured data; for example the sharp drop in power output between columns 1 and 2 and the further reduction in power at a shallower gradient through the rest of the wind farm; also the increased power deficit towards the inner rows of the wind farm. In all flow cases however there is a difference between the modelled and measured power for the turbines in the upstream column A, which are unaffected by other turbines; the measured power is significantly less than the power curve value corresponding to the flow case wind

20 speed. This could be due to not accounting for the $\pm 0.5 \mathrm{~ms}^{-1}$ variation in the upstream wind speed in the modelling, or the power curve being inaccurate, or the mean inflow wind speed in each case being lower than the nominal flow case wind speed.

\section{Summary and Conclusions}

FLOWSTAR-Energy has been developed as a practical tool for wind farm energy calculations and for predicting the effect

25 of wind farms on the local flow and turbulence at high resolution. The model takes account of atmospheric stability effects, wind turbine wakes and the differences in atmospheric boundary layer structure between the land and the sea.

The ability of the model to replicate measured wind turbine power levels has been tested by comparing model results with three measurement datasets and the results have been presented here. Two of the three datasets are offshore wind farms and include stability distribution data, which were included in the modelling. Of the two offshore wind farm datasets, the

30 Noordzee dataset focuses on a single 5-degree wind direction sector and therefore only represents a limited number of measurements $(1,284)$; whereas the Nysted dataset captures data for seven 5-degree wind direction sectors and represents a larger number of measurements $(84,363)$. The best agreement between modelled and measured data was obtained with the 
Wind Energ. Sci. Discuss., doi:10.5194/wes-2016-34, 2016

Manuscript under review for journal Wind Energ. Sci.

Published: 28 September 2016

(c) Author(s) 2016. CC-BY 3.0 License.

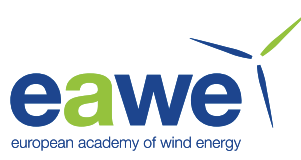

Nysted dataset, with high correlation ( 0.98 or above) and low normalised mean square error ( 0.007 or below) for all three flow cases. The results from the single-turbine validation case, Tjæreborg, show that the model replicates the Gaussian shape of the wake deficit two turbine diameters downstream of the turbine, but the lack of stability information in this dataset makes it difficult to draw conclusions about model performance.

5 In addition to predicting power output from individual wind turbines, FLOWSTAR-Energy predicts the 3D flow and turbulence on a high resolution grid of receptors in and around a wind farm; maps of wind speed and turbulence have been presented here for the offshore wind farm cases.

One of the key strengths of FLOWSTAR-Energy is its ability to model the effects of complex terrain on the airflow. However, although the airflow model has been compared extensively with flow data (e.g. Carruthers et al., 2014, Stocker et

10 al., 2016, CERC, 2016 - Askervein Hill and Blashaval), it has so far not been used in detail to predict energy yields from wind farms in complex terrain. This will be the subject of a further validation study for FLOWSTAR-Energy.

\section{Acknowledgements}

The authors are very grateful to Kurt Schaldemose Hansen of DTU's Wind Energy department for providing the measured data and wind farm specification presented in this report during the course of the EU's FP6 TOPFARM project, in which

15 CERC and DTU were both partners.

\section{References}

Barthelmie, R.J., Frandsen, S.T., Hansen, K., Schepers, J.G., Rados, K., Schlez, W., Neubert, A., Jensen, L.E., Neckelmann, S., 2009: Modelling the impact of wakes on power output at Nysted and Horns Rev. European Wind Energy Conference and Exhibition, Marseille, 2009.

20 Beljaars, A. C. M., 1994: The parameterisation of surface fluxes in large-scale models under free convection. Quart. J. R. Met. Soc., 121, pp. 255-270

Bevilaqua, P.M. and Lykoudis, P.S., 1978: Turbulence memory in self-preserving wakes. J. Fluid Mech., 89, pp. 589-606. Carruthers, D.J., Ellis, A.E., Hunt, J.C.R and Chan, P.W., 2014: Modelling of wind shear downwind of mountain ridges at Hong Kong International Airport. Meteorological Applications, 21, pp. 94-104.

25 Carruthers, D.J., Hunt, J.C.R. and Weng, W.-S., 1988: A computational model of stratified turbulent airflow over hills - FLOWSTAR I. Computer Techniques in Environmental Studies, pp. 481-492. Ed. P. Zanetti, Springer-Verlag. CERC, 2016: FLOWSTAR-Energy Complex Terrain Flow Field Validation: Askervein Hill CERC, 2016: FLOWSTAR-Energy Complex Terrain Flow Field Validation: Blashaval CERC, 2015: ADMS 5 Technical Specification.

30 Hanna, S.R. and Paine, R.J., 1989: Hybrid plume dispersion model (HPDM) development and evaluation. J. Appl. Meteorol., 28, pp. 206-224.

Hansen, K. S., 2009. Wake measurements for code validations: Deliverable D11: EU - TOPFARM. (1 ed.). Hansen, M.O.L., 2008: Aerodynamics of wind turbines. Second edition. Earthscan.

Hunt, J.C.R., Holroyd, R.J and Carruthers, D.J., 1988a: Preparatory studies for a complex dispersion model. CERC Report HB9/88. 
Wind Energ. Sci. Discuss., doi:10.5194/wes-2016-34, 2016

Manuscript under review for journal Wind Energ. Sci.

Published: 28 September 2016

(c) Author(s) 2016. CC-BY 3.0 License.

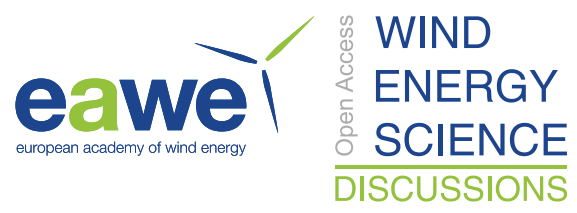

(c) (i)

Larsen, G.C., Madsen, H.A., Troldborg, N., Larsen, T.J., Réthoré, P-E., Fuglsang, P., Ott, S., Mann, J., Buhl, T., Nielsen, M., Markou, H., Sørensen, J.N., Hansen, K.S., Mikkelsen, R., Okulov, V., Shen, W.Z., Heath, M., King, J., McCann, G., Schlez, W., Carlén, I., Ganander, H., Migoya, E., Crespo, A., Jiménez, A., Prieto, J.L., Stidworthy, A.L., Carruthers, D.J., Hunt, J.C.R., Gray, S., Veldkamp, D., Mouritzen, A.S., Jensen, L., Krogh, T., Schmidt, B., Argyriadis, K. and Larsen P.F., 2011:

5 TOPFARM - Next generation design tool for optimisation of wind farm topology and operation. Publishable final activity report. Ris $\varnothing-$ R-1805 (EN), Risø DTU, Roskilde, Denmark.

Sanderse, B., van der Pijl, S.P. and Koren, B., 2011: Review of computational fluid dynamics for wind turbine wake aerodynamics. Wind Energy, 14, pp. 799-819.

Stocker, J., Carruthers, D. J., Johnson, K., Hunt, J.C.R. and Chan, P. W., 2016: Optimized use of real-time vertical-profile

10 wind data and fast modelling for prediction of airflow over complex terrain. Meteorological Applications, 23, pp. 182-190. Weil, J.C., 1985: Updating applied diffusion models. J. Clim. Appl. Met., 24, pp. 1111-1130.

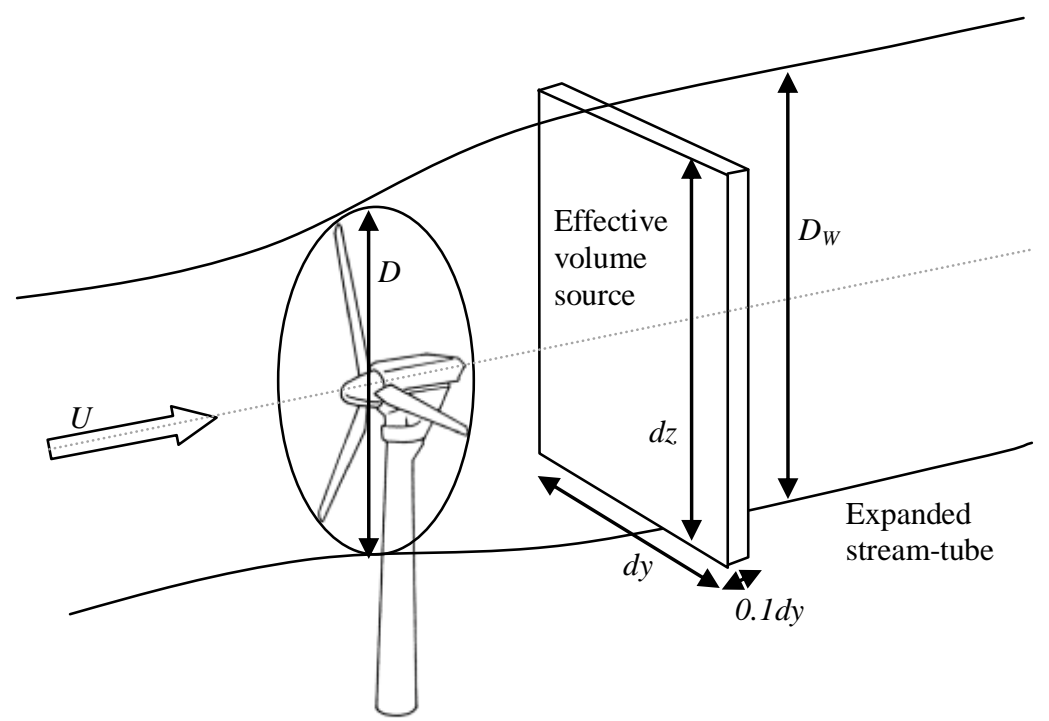

Figure 1: Schematic of the expanding stream-tube of air flowing through the wind turbine rotor, and the effective volume source representing that wind turbine. 
Wind Energ. Sci. Discuss., doi:10.5194/wes-2016-34, 2016

Manuscript under review for journal Wind Energ. Sci.

Published: 28 September 2016

(c) Author(s) 2016. CC-BY 3.0 License.

(c) (i)
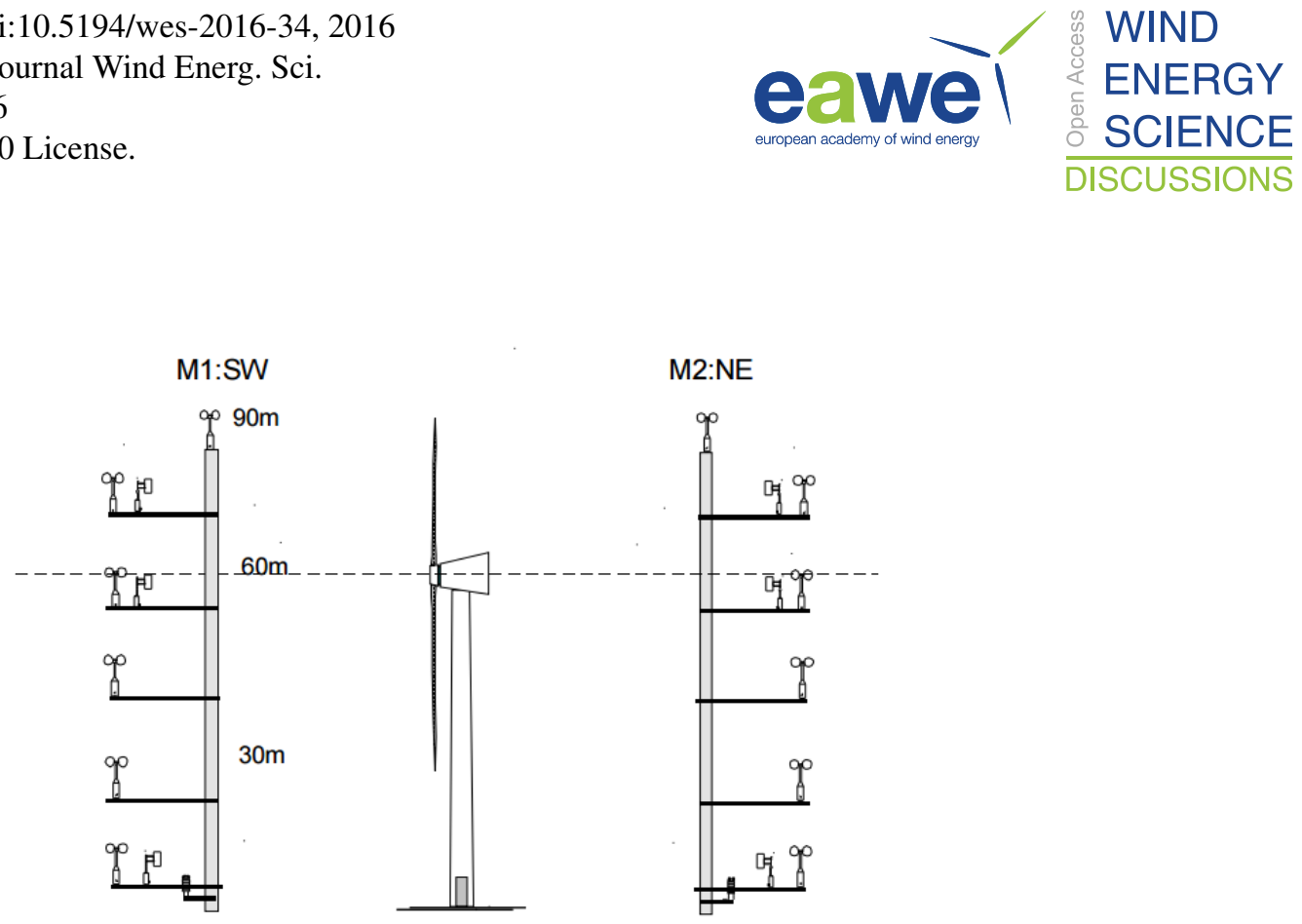

Figure 2: Schematic diagram of the Tjæreborg site, showing the instrumentation on the two meteorological masts, upstream (M1) and downstream (M2) of the turbine (Hansen, 2009).

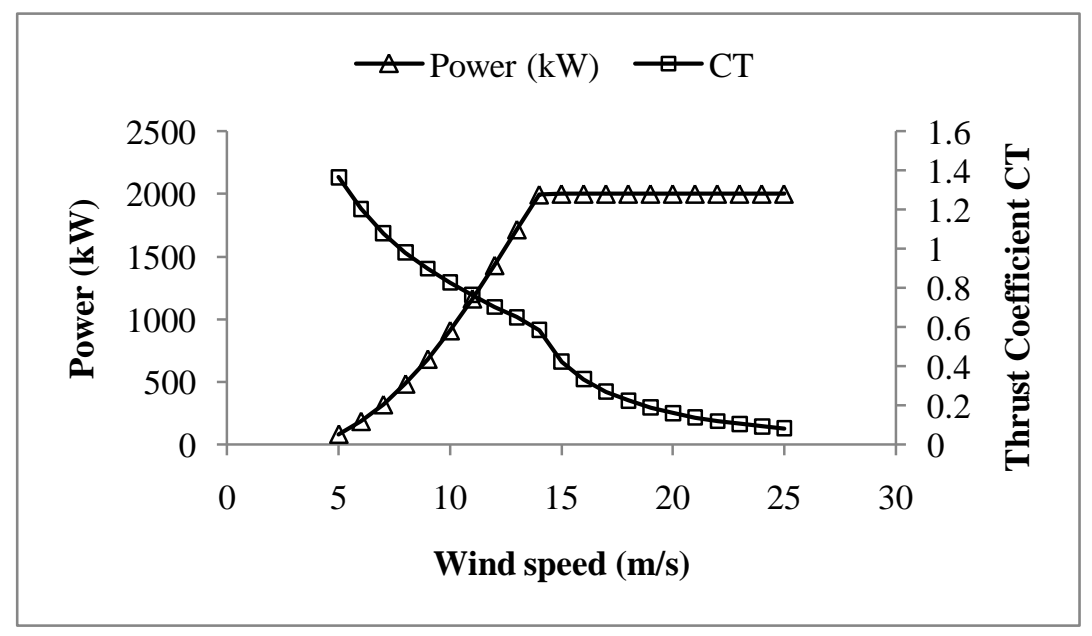

5 Figure 3: Power $(\mathrm{kW})$ and thrust coefficient $C_{T}$ as a function of hub height wind speed. 
Wind Energ. Sci. Discuss., doi:10.5194/wes-2016-34, 2016

Manuscript under review for journal Wind Energ. Sci.

Published: 28 September 2016

(c) Author(s) 2016. CC-BY 3.0 License.

(c) (i)
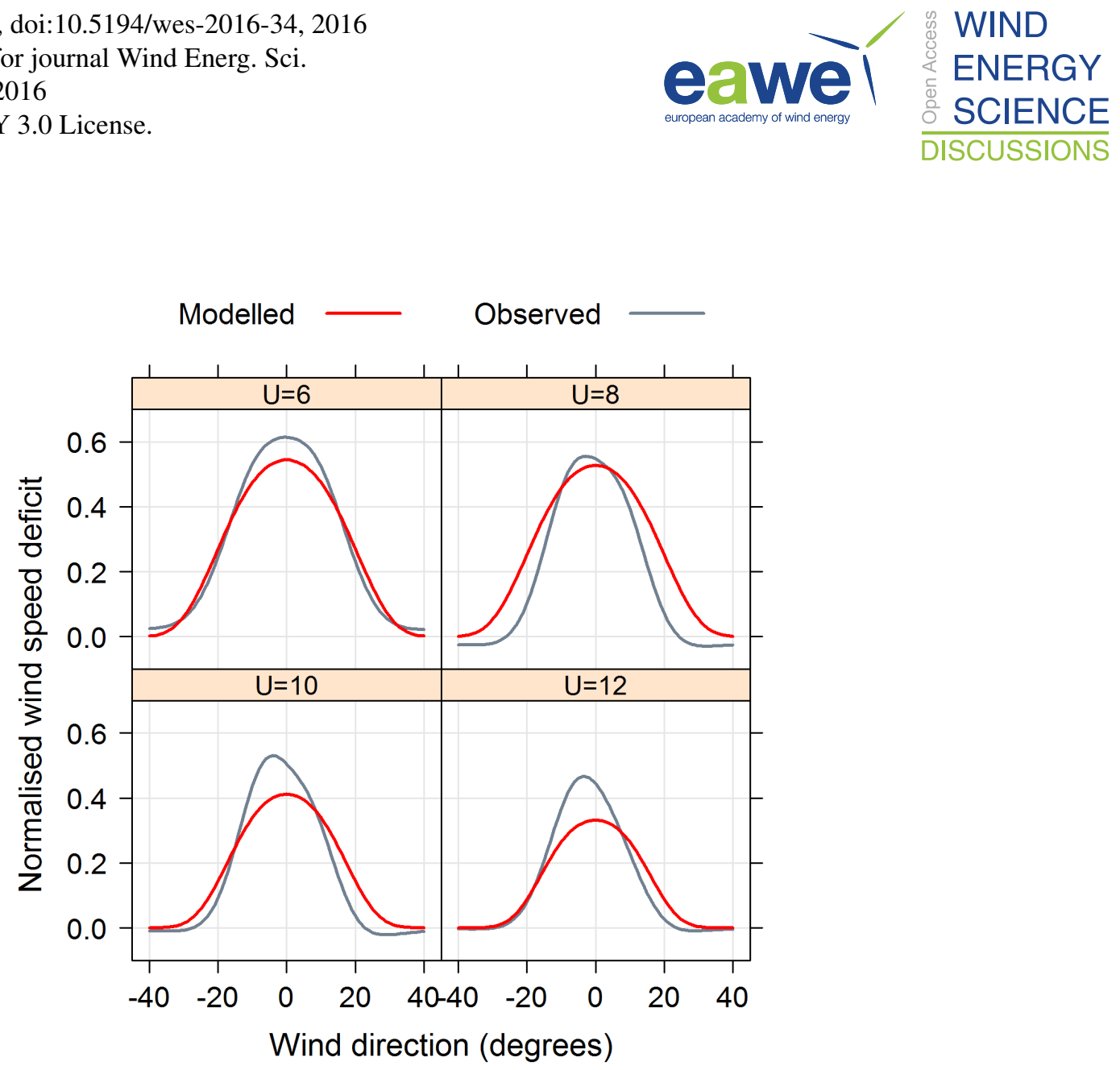

Figure 4: Normalised modelled and observed wind speed deficit at the receptor for the 4 flow cases $\left(U=6,8,10\right.$ and $\left.12 \mathrm{~ms}^{-1}\right)$ across the range of upstream wind directions, averaged over the 4 measurement heights $(30,45,60$ and $90 \mathrm{~m})$. 
Wind Energ. Sci. Discuss., doi:10.5194/wes-2016-34, 2016

Manuscript under review for journal Wind Energ. Sci.

Published: 28 September 2016

(c) Author(s) 2016. CC-BY 3.0 License.

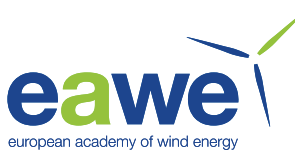

(c) (i)

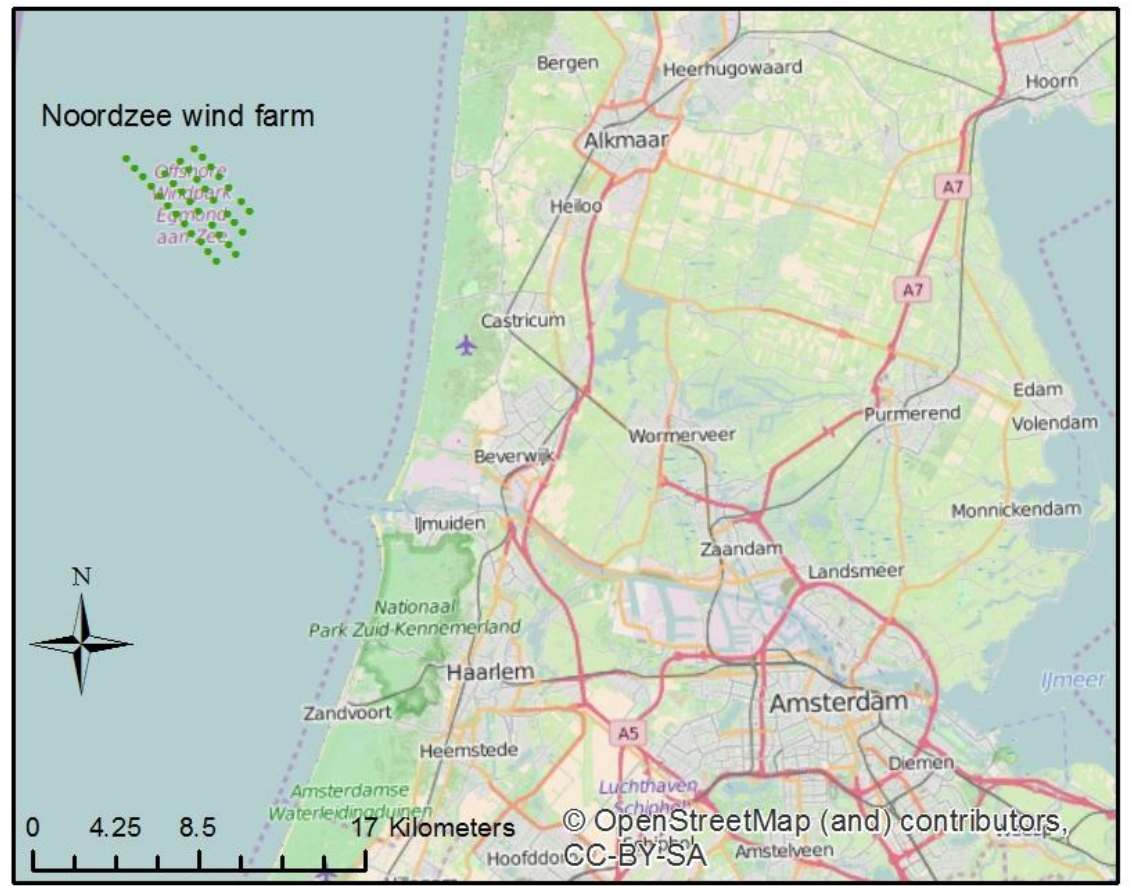

Figure 5: Map showing the location of the NoordZee wind farm and the coast of the Netherlands. Individual wind turbine positions are shown by green dots.

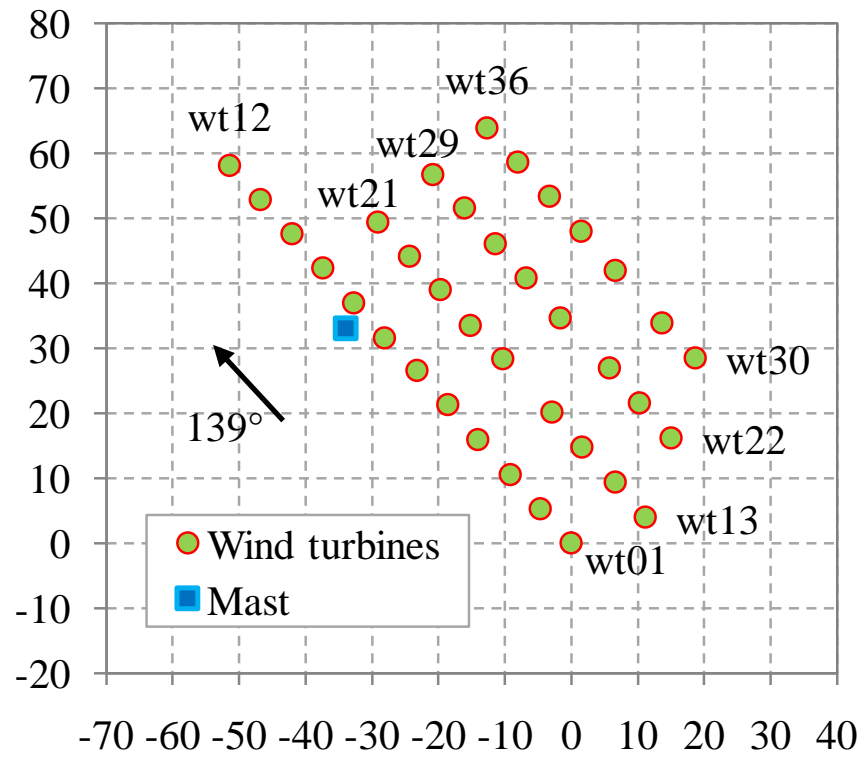

5 Figure 6: Layout of the NoordZee wind farm. Distance unit is rotor diameters $(90 \mathrm{~m})$. 
Wind Energ. Sci. Discuss., doi:10.5194/wes-2016-34, 2016

Manuscript under review for journal Wind Energ. Sci.

Published: 28 September 2016

(c) Author(s) 2016. CC-BY 3.0 License.

(c) (i)
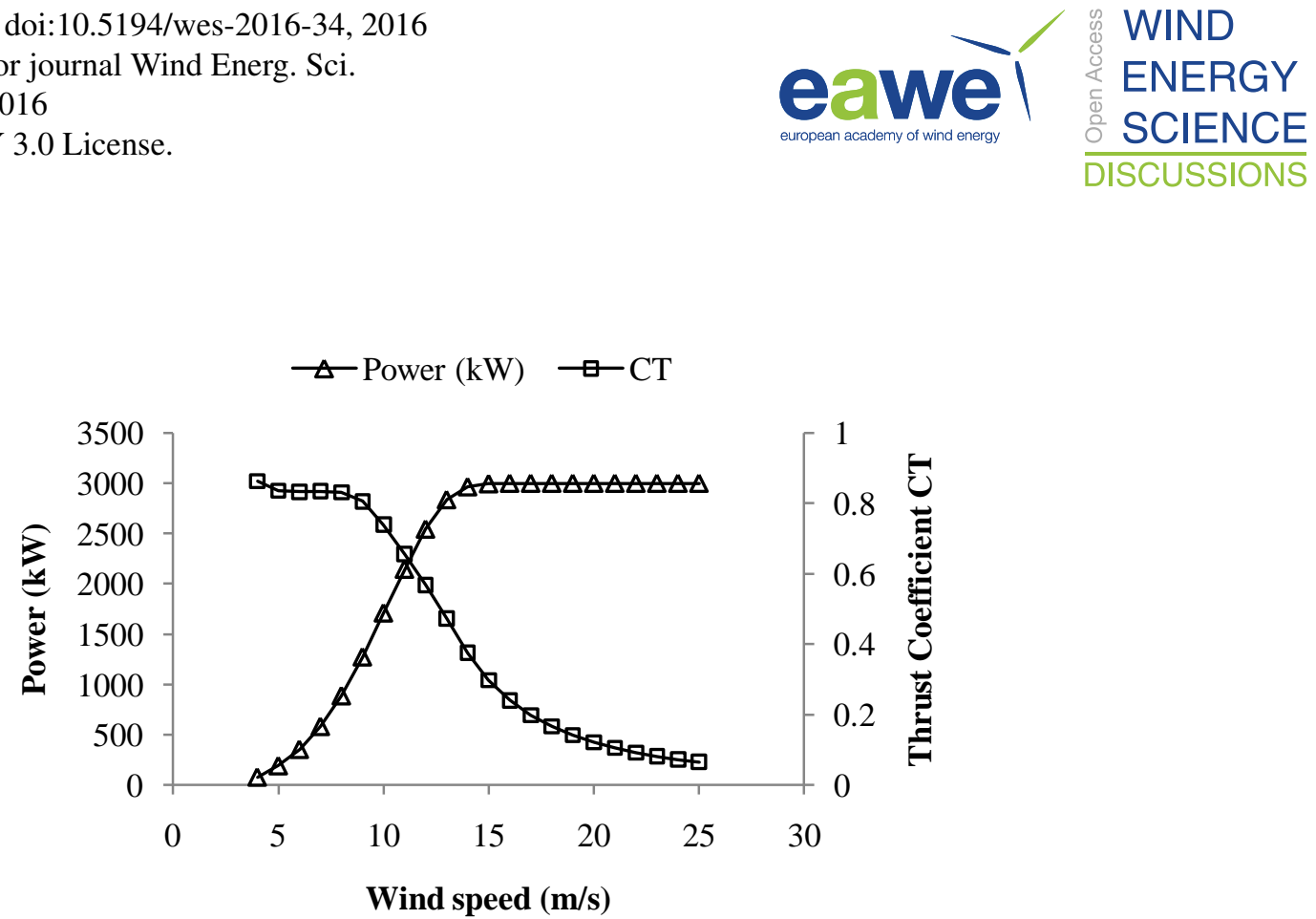

Figure 7: Power output $(\mathrm{kW})$ and thrust coefficient $C_{T}$ as a function of inflow wind speed for the V90 VESTAS 3 MW turbines installed at the NoordZee wind farm. 
Wind Energ. Sci. Discuss., doi:10.5194/wes-2016-34, 2016

Manuscript under review for journal Wind Energ. Sci.

Published: 28 September 2016

(c) Author(s) 2016. CC-BY 3.0 License.

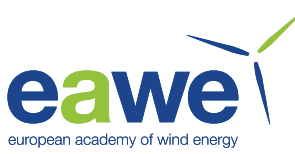

(c) (i)

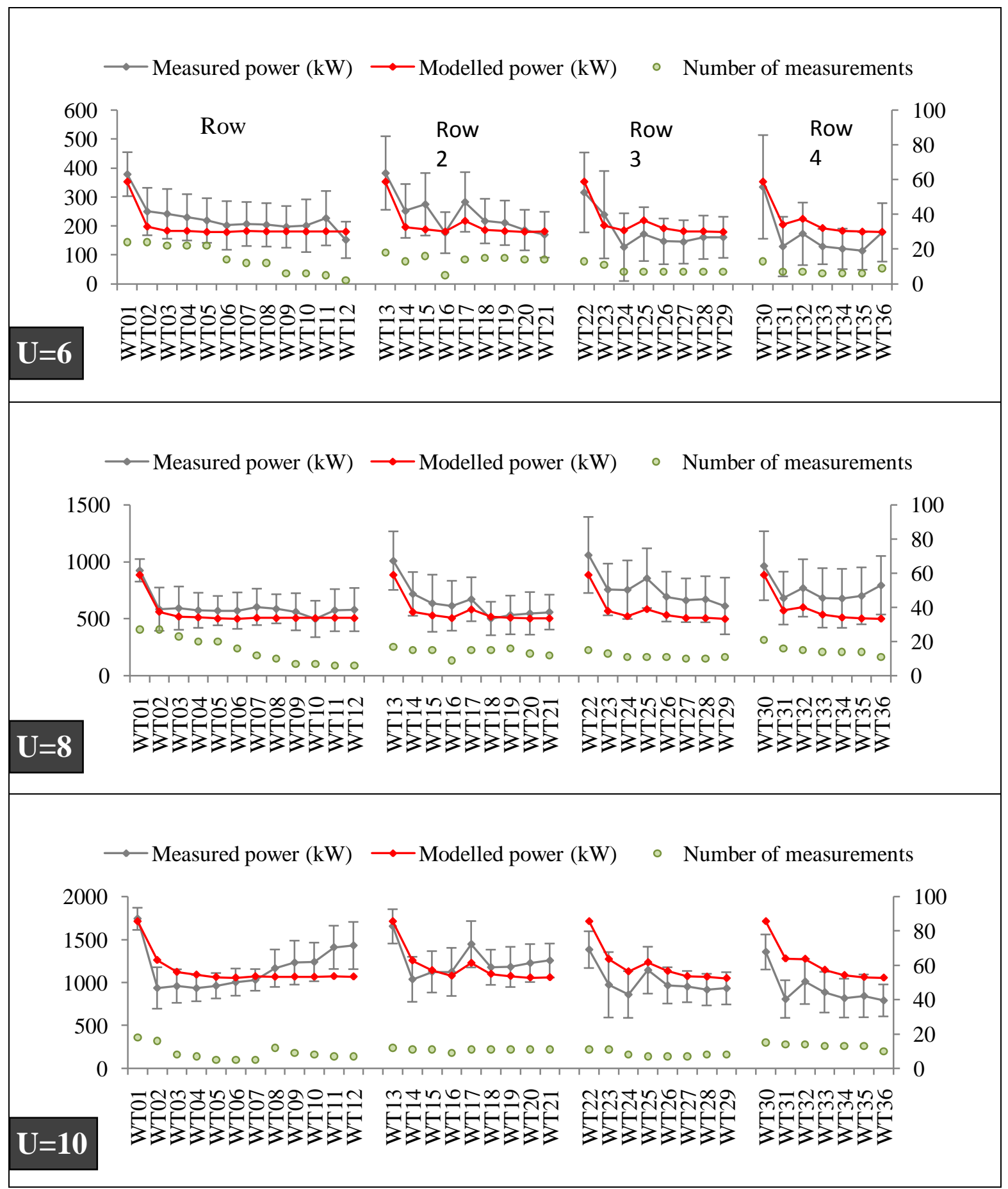

Figure 8: Power output $(\mathrm{kW})$ for individual wind turbines by flow case. Modelled values are shown by the red line; mean measured values are shown by the grey line. The error bars show the standard deviation of the 10-minute measurements used to calculate the mean and the green circles show the number of measurements used to calculate the mean value in each case. The turbine name is shown on the $\mathrm{x}$-axis; the power output $(\mathrm{kW})$ is shown on the primary $\mathrm{y}$-axis (left); the number of measurements is shown on the secondary y-axis (right). 
Wind Energ. Sci. Discuss., doi:10.5194/wes-2016-34, 2016

Manuscript under review for journal Wind Energ. Sci.

Published: 28 September 2016

(c) Author(s) 2016. CC-BY 3.0 License.
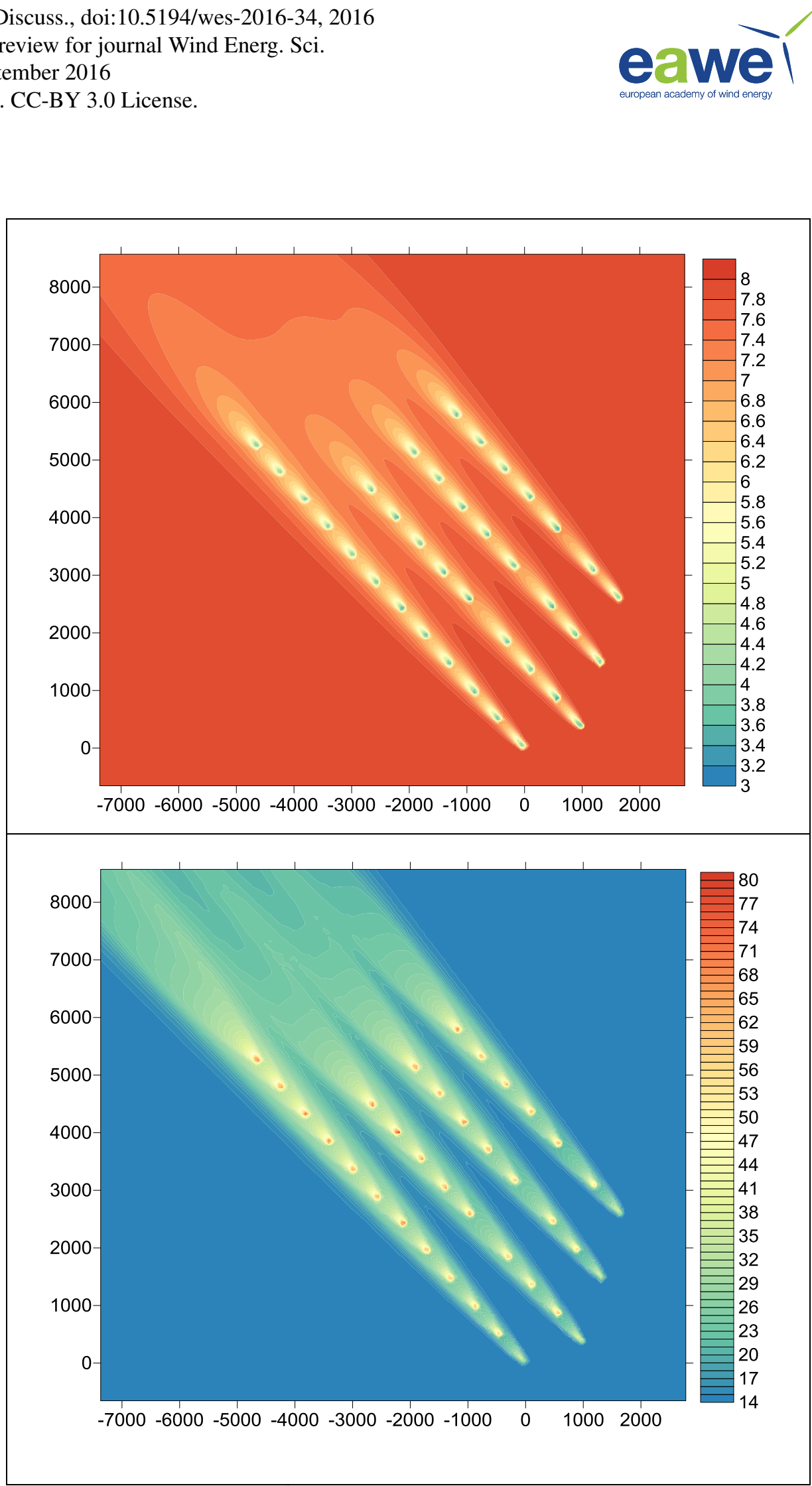

Figure 9: Modelled horizontal wind speed (top, $\mathrm{ms}^{-1}$ ) and turbulence intensity (bottom, \%) over the NoordZee wind farm for the 8 $\mathrm{ms}^{-1}$ flow case. Coordinates in metres are relative to the reference turbine wt01. Modelled output grid resolution in this case is approximately $50 \mathrm{~m}$. 
Wind Energ. Sci. Discuss., doi:10.5194/wes-2016-34, 2016

Manuscript under review for journal Wind Energ. Sci.

Published: 28 September 2016

(c) Author(s) 2016. CC-BY 3.0 License.
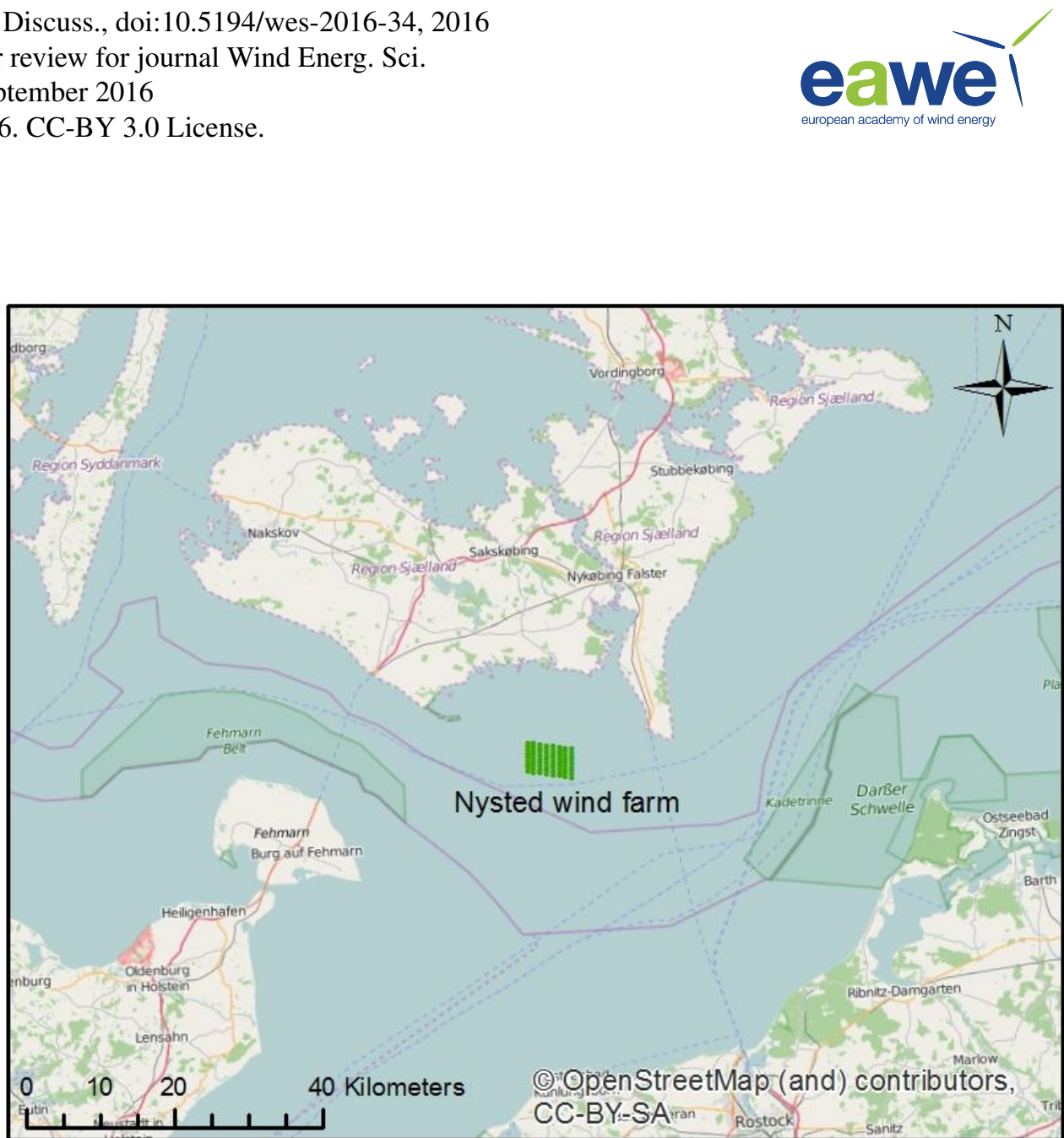

Figure 10: Map showing the location of the Nysted wind farm andthe coast of Denmark. Individual wind turbine positions are shown by green dots.

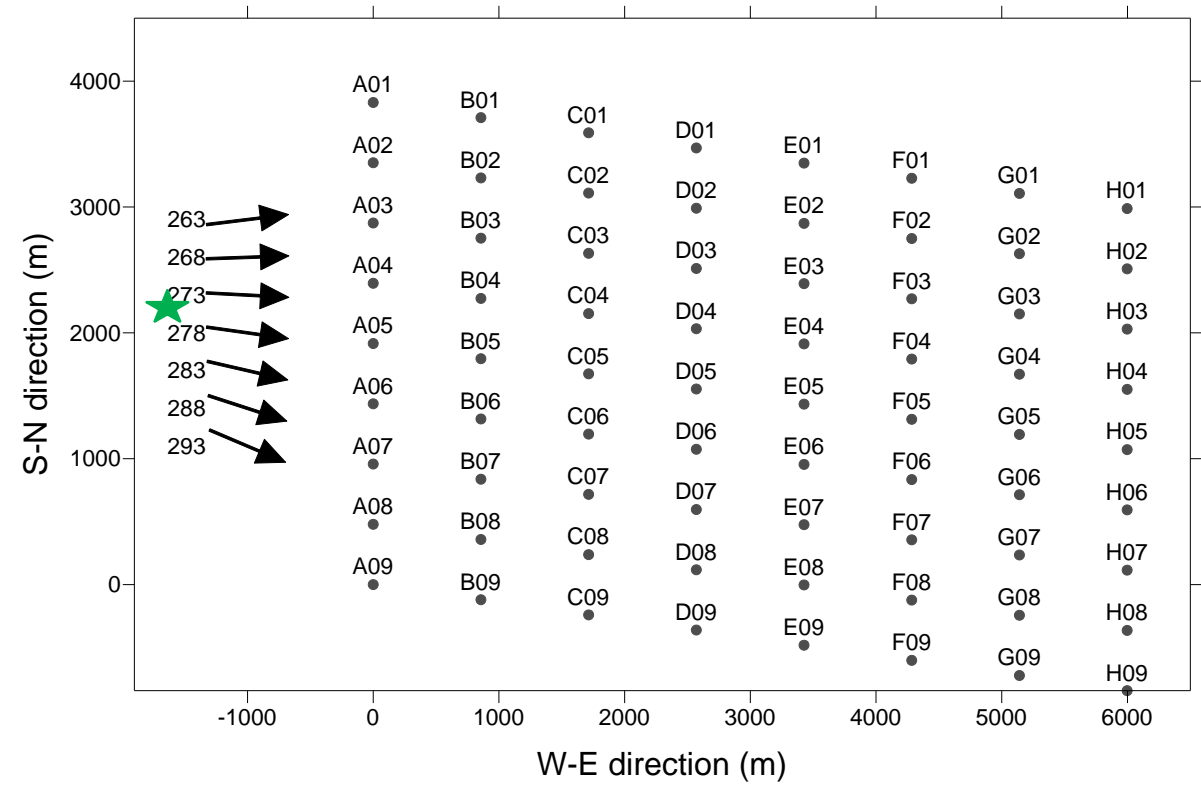

5 Figure 11: Layout of wind turbines in the Nysted wind farm. The green star marks the location of the meteorological mast. 
Wind Energ. Sci. Discuss., doi:10.5194/wes-2016-34, 2016

Manuscript under review for journal Wind Energ. Sci.

Published: 28 September 2016

(c) Author(s) 2016. CC-BY 3.0 License.

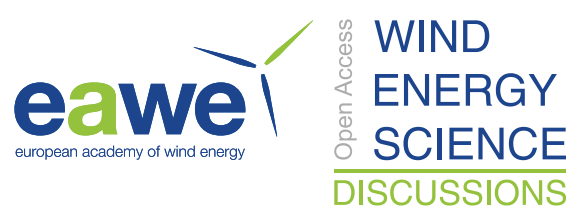

(c) (i)

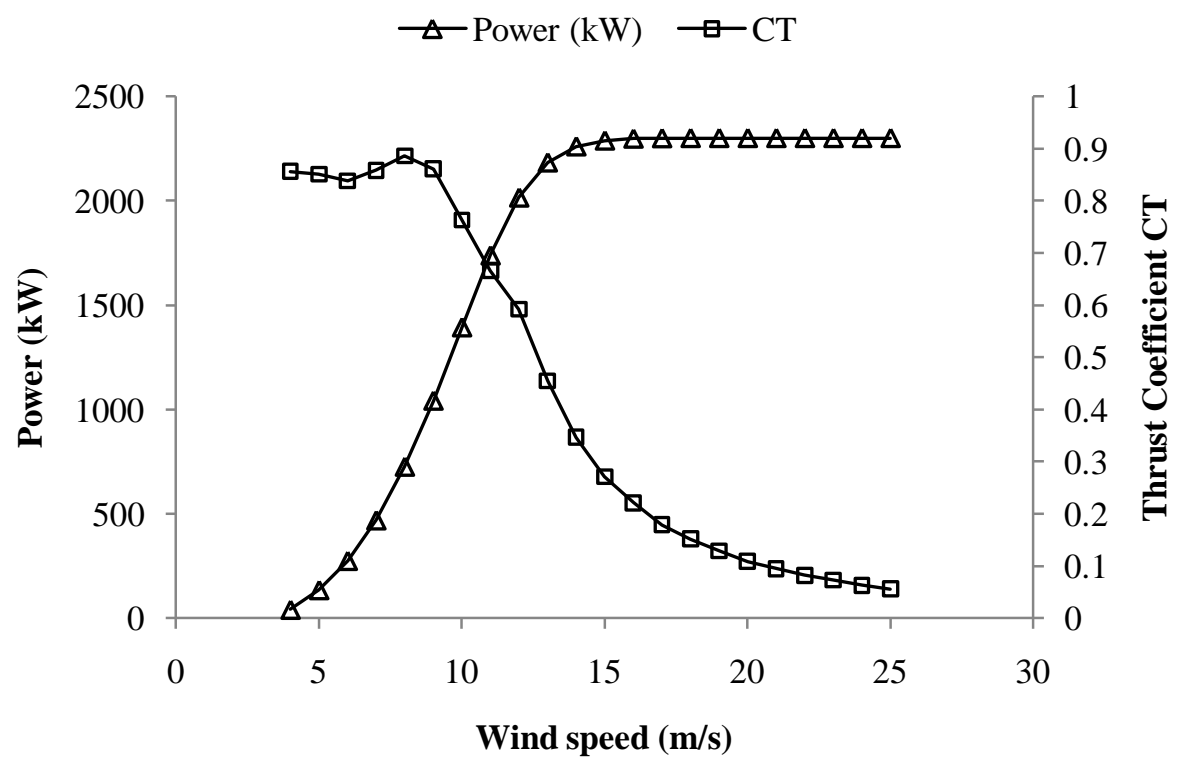

Figure 12: Power output $(\mathrm{kW})$ and thrust coefficient $C_{T}$ as a function of inflow wind speed for the Bonus 2.3 MW turbines installed at the Nysted wind farm. 
Wind Energ. Sci. Discuss., doi:10.5194/wes-2016-34, 2016

Manuscript under review for journal Wind Energ. Sci.

Published: 28 September 2016

(c) Author(s) 2016. CC-BY 3.0 License.
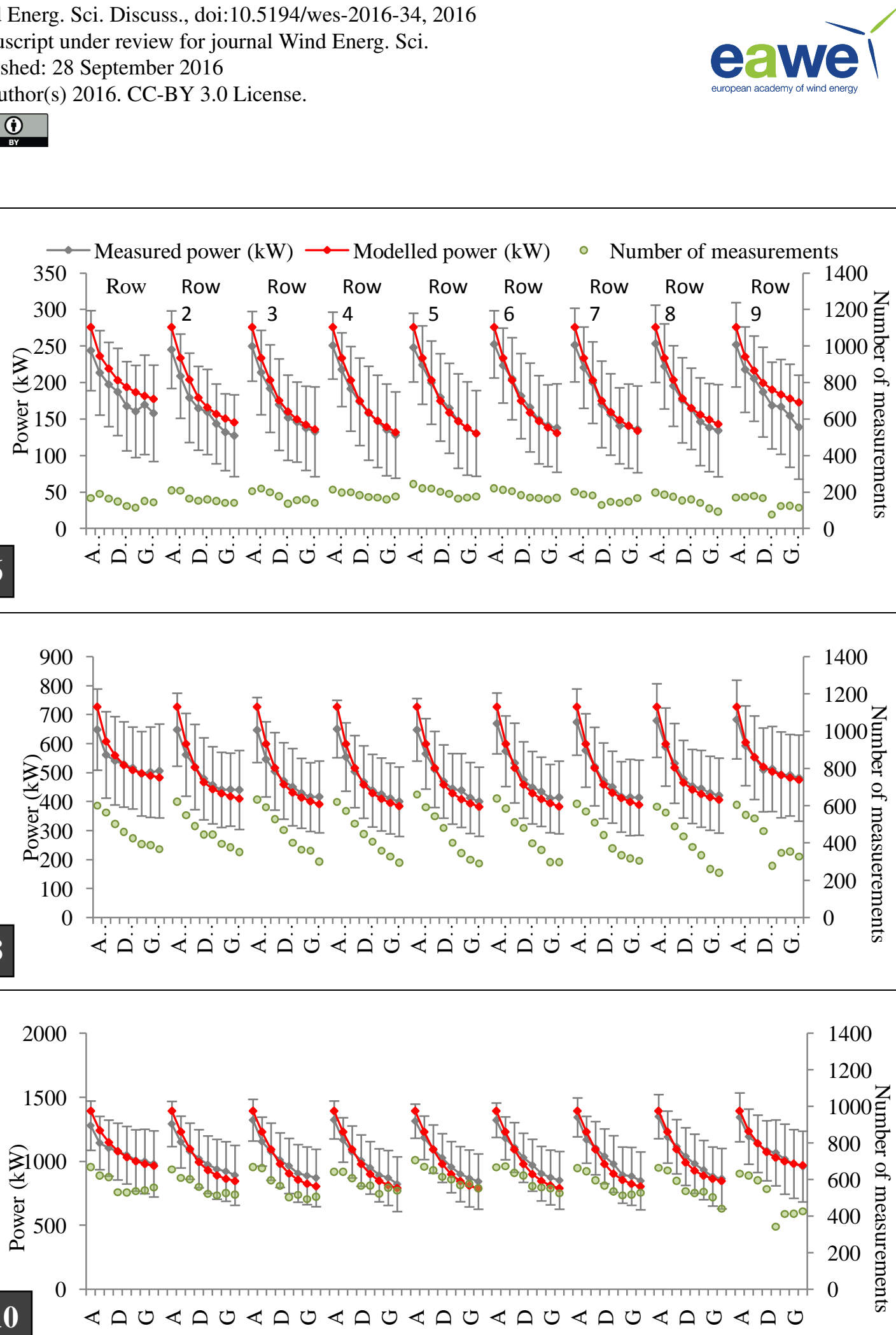

Figure 13: Measured and modelled power $(\mathrm{kW})$ at each Nysted turbine for each of the 3 flow cases, averaged over the 7 wind direction cases. The red lines show the modelled power; the grey lines show the mean measured power; and the error bars show the standard deviation in the measurements used to calculate the mean value. The green circles show the number of measurements used to calculate the mean value. 
Wind Energ. Sci. Discuss., doi:10.5194/wes-2016-34, 2016

Manuscript under review for journal Wind Energ. Sci.

Published: 28 September 2016

(c) Author(s) 2016. CC-BY 3.0 License.
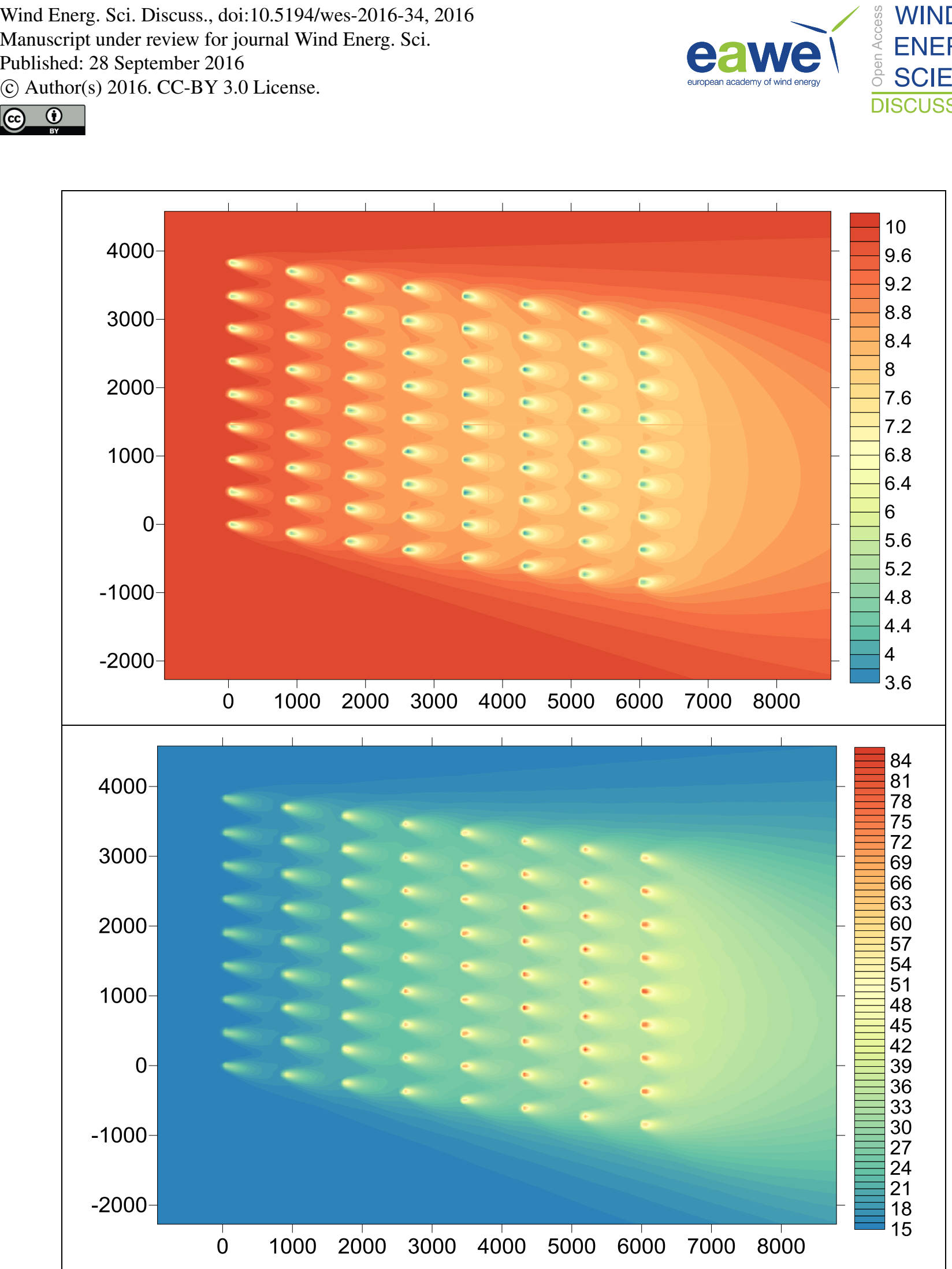

Figure 14: Modelled horizontal wind speed (top, $\mathrm{ms}^{-1}$ ) and turbulence intensity (bottom, \%) over the Nysted wind farm for the 10 $\mathrm{ms}^{-1}$ flow case, averaged over the 7 wind direction cases. Coordinates are relative to the position of the turbine A09. Modelled output grid resolution in this case is approximately $50 \mathrm{~m}$. 
Wind Energ. Sci. Discuss., doi:10.5194/wes-2016-34, 2016

Manuscript under review for journal Wind Energ. Sci.

Published: 28 September 2016

(c) Author(s) 2016. CC-BY 3.0 License.

\begin{tabular}{lccccc}
\hline Dataset & $\begin{array}{c}\text { Number } \\
\text { of wind } \\
\text { turbines }\end{array}$ & $\begin{array}{c}\text { Onshore or } \\
\text { offshore } \\
\text { dataset }\end{array}$ & $\begin{array}{c}\text { Turbine } \\
\text { diameter } \\
(\mathbf{m})\end{array}$ & $\begin{array}{c}\text { Turbine hub } \\
\text { height }(\mathbf{m})\end{array}$ & $\begin{array}{c}\text { Turbine rated } \\
\text { power (MW) }\end{array}$ \\
\hline Tjæreborg 60 m turbine & 1 & Onshore & 61.0 & 60 & 2.0 \\
Noordzee wind farm & 36 & Offshore & 90.0 & 70 & 3.0 \\
Nysted wind farm & 72 & Offshore & 82.4 & 69 & 2.3 \\
\hline
\end{tabular}

Table 1: Summary of validation cases

\begin{tabular}{lll}
\hline Name & Description & Equation \\
\hline$\sigma_{P}$ & Standard Deviation & $\sqrt{1 / n \sum(P-\bar{P})^{2}}$ \\
R & Pearson's Correlation Coefficient & $\operatorname{cov}\left(P_{m}, P_{o}\right) / \sigma_{P_{m}} \sigma_{P_{o}}$ \\
FB & Fractional Bias & $\left(\overline{P_{m}}-\overline{P_{o}}\right) / 0.5\left(\overline{P_{o}}+\overline{P_{m}}\right)$ \\
NMSE & Normalised Mean-Square-Error & $\frac{\left(P_{m}-P_{o}\right)^{2}}{P_{o} P_{m}}$ \\
\hline
\end{tabular}

Table 2: Definition of the statistical measures used to compare modelled and observed data. ' $P$ ' indicates a power value; the suffix ' $m$ ' indicates modelled data; the suffix ' 0 ' indicates observed data; $n$ is the number of data points.

5

\begin{tabular}{|c|c|c|c|c|c|c|}
\hline \multirow[t]{2}{*}{ Description } & \multirow[t]{2}{*}{ Class } & \multirow[t]{2}{*}{ Range of $L_{M O}$} & \multirow[t]{2}{*}{$\begin{array}{c}\text { Representative } \\
\mathbf{L}_{M O}\end{array}$} & \multicolumn{3}{|c|}{$\begin{array}{c}\text { Distribution by flow case } \\
(\%)\end{array}$} \\
\hline & & & & $6 \mathrm{~ms}^{-1}$ & $8 \mathrm{~ms}^{-1}$ & $10 \mathrm{~ms}^{-1}$ \\
\hline Very unstable & -3 & $-100 \leq L_{M O}<-50$ & -75 & 59 & 100 & 100 \\
\hline Unstable & -2 & $-200 \leq L_{M O}<-100$ & -150 & 23 & 0 & 0 \\
\hline Near unstable & -1 & $-500 \leq L_{M O}<-200$ & -350 & 5 & 0 & 0 \\
\hline Neutral & 0 & $\left|L_{M O}\right|>500$ & $10^{6}$ & 13 & 0 & 0 \\
\hline Near stable & 1 & $200 \leq L_{M O}<500$ & 350 & 0 & 0 & 0 \\
\hline Stable & 2 & $50 \leq L_{M O}<200$ & 125 & 0 & 0 & 0 \\
\hline Very stable & 3 & $10 \leq L_{M O}<50$ & 30 & 0 & 0 & 0 \\
\hline
\end{tabular}

Table 3: Definition of stability classes used in the Noordzee dataset, together with the stability distribution of measurements by flow case.

\begin{tabular}{|c|c|c|c|c|c|c|c|}
\hline \multirow{2}{*}{$\begin{array}{l}\text { Flow } \\
\text { case } \\
\left(\mathbf{m s}^{-1}\right)\end{array}$} & \multirow{2}{*}{$\begin{array}{l}\text { Calculated } \\
\text { surface } \\
\text { roughness } \\
\text { length } \mathrm{z}_{0} \\
\text { (m) }\end{array}$} & \multirow{2}{*}{$\begin{array}{c}\text { Number } \\
\text { of } \\
\text { measure- } \\
\text { ments }\end{array}$} & \multicolumn{2}{|c|}{$\begin{array}{l}\text { Farm total } \\
\text { power }(k W)\end{array}$} & \multirow{2}{*}{$\begin{array}{l}\text { Correlation } \\
\text { (R) }\end{array}$} & \multirow{2}{*}{$\begin{array}{c}\text { Fractional } \\
\text { bias (FB) }\end{array}$} & \multirow{2}{*}{$\begin{array}{c}\text { Normalised } \\
\text { mean square } \\
\text { error (NMSE) }\end{array}$} \\
\hline & & & Measured & Modelled & & & \\
\hline 6 & 0.00032 & 415 & 7,511 & 7,350 & 0.77 & -0.022 & 0.041 \\
\hline 8 & 0.00068 & 505 & 24,352 & 20,375 & 0.86 & -0.178 & 0.044 \\
\hline 10 & 0.00096 & 364 & 39,899 & 42,633 & 0.57 & 0.066 & 0.035 \\
\hline
\end{tabular}

Table 4: Calculated surface roughness length, measured and modelled total power $(\mathrm{kW})$ of the NoordZee wind farm for each flow 10 case; and the correlation, fractional bias and normalised mean square error between the measured and modelled individual turbine power values. 
Wind Energ. Sci. Discuss., doi:10.5194/wes-2016-34, 2016

Manuscript under review for journal Wind Energ. Sci.

Published: 28 September 2016

(c) Author(s) 2016. CC-BY 3.0 License.

\begin{tabular}{|c|c|c|c|c|c|c|c|}
\hline \multirow{2}{*}{ Description } & \multirow{2}{*}{ Class } & \multirow{2}{*}{ Definition } & \multirow{2}{*}{$\mathrm{z} / \mathbf{L}_{\mathrm{MO}}$} & \multirow{2}{*}{$1 / \mathbf{L}_{M O}$} & \multicolumn{3}{|c|}{ Distribution by flow case $(\%)$} \\
\hline & & & & & $6 \mathrm{~ms}^{-1}$ & $8 \mathrm{~ms}^{-1}$ & $10 \mathrm{~ms}^{-1}$ \\
\hline Very unstable & 1 & $-100000 \leq z / L_{M O}<-12$ & -100 & -1.44928 & 20.5 & 3.8 & 0.1 \\
\hline Unstable & 2 & $-12 \leq z / L_{M O}<-2$ & -5 & -0.07246 & 24.9 & 30.3 & 18.4 \\
\hline Near neutral & 3 & $-2 \leq z / L_{M O}<0$ & -0.5 & -0.00725 & 31.9 & 49.1 & 67.5 \\
\hline Near neutral & 4 & $0 \leq z / L_{M O}<2$ & 0.5 & 0.00725 & 8.9 & 9.9 & 12.1 \\
\hline Stable & 5 & $2 \leq z / L_{M O}<12$ & 5 & 0.07246 & 0.4 & 0.3 & 0.4 \\
\hline Very stable & 6 & $12 \leq z / L_{M O}<100000$ & 100 & 1.44928 & 13.4 & 6.5 & 1.4 \\
\hline
\end{tabular}

Table 5: Definition of stability classes given in the Nysted dataset. For the calculation of the representative value of $1 / L_{M O}, z$ was taken to be the hub height $(69 \mathrm{~m})$.

5

\begin{tabular}{ccccccccc}
\hline \multirow{2}{*}{$\begin{array}{c}\text { Flow } \\
\text { case } \\
\left(\mathbf{m s}^{-1}\right)\end{array}$} & $\begin{array}{c}\text { Calculated } \\
\text { surface } \\
\text { roughness } \\
\text { length } \mathbf{z}_{\mathbf{0}}(\mathbf{m})\end{array}$ & $\begin{array}{c}\text { Number } \\
\text { of } \\
\text { measure- } \\
\text { ments }\end{array}$ & \multicolumn{2}{c}{ Farm total power $(\mathbf{k W})$} & Measured & Modelled & & Correlation \\
& $\mathbf{R})$ & $\begin{array}{c}\text { Fractional } \\
\text { bias (FB) }\end{array}$ & $\begin{array}{c}\text { Normalised } \\
\text { mean square } \\
\text { error (NMSE) }\end{array}$ \\
\hline 6 & 0.00032 & 12,091 & 12,872 & 13,681 & 0.98 & 0.061 & 0.007 \\
8 & 0.00062 & 31,974 & 36,160 & 36,388 & 0.99 & 0.006 & 0.003 \\
10 & 0.00107 & 40,298 & 74,976 & 74,391 & 0.99 & -0.008 & 0.002
\end{tabular}

Table 6: Calculated surface roughness length, measured and modelled total power $(\mathrm{kW})$ of the Nysted wind farm for each flow case, averaged over all seven wind direction cases; and the correlation, fractional bias and normalised mean square error between the measured and modelled individual turbine power values, when averaged across all seven wind direction cases. 